\title{
Hospitality industry employer's expectation of employees' competences in Nairobi Hotels
}

\author{
Sarah W. Kamau ${ }^{1 *}$ and Judith Waudo ${ }^{2}$ \\ ${ }^{1}$ Hospitality Management Institution, Kenya Utalii College, P. O. Box 63104-0619, Nairobi. \\ ${ }^{2}$ Department of Hospitality, Kenyatta University, P. O. Box 43844, Nairobi.
}

Accepted 10 February, 2012

\begin{abstract}
The purpose of the study was to determine the expectations of hospitality industry employers on employees' competences. The sample (106) was made up of Human Resource Managers (HRMs) Head of Departments (HODs) and employees. Results indicated a big differential on employers and employees' expectations on communication skills, specific technical skills, computer, good work habits, customer service and self-discipline. The employees' expectations were higher than that of the employer's apart from conflict resolution and multi-skilling where the employers' expectations were higher. In addition, there was a significant relationship between employer's expectation of employee competences and the hotel classification. It is only in computer skills $(p=0.04)$ where there was no significant relationship. The findings suggested the establishment of hospitality industry standards which should be communicated to all employers, employees and training providers. The industry and training provider to be linked and both should embrace the use of updated management to be globally competitive.
\end{abstract}

Key words: Hospitality industry, employers' expectations, employees' competence, skills, Nairobi Hotels.

\section{INTRODUCTION}

The hospitality industry dates back to 2000 years ago in the Middle East. Its development was due to the evolvement of the transport industry (King and Smith, 2005). This led to the demand for trained personnel. Despite this, Tourism Education and Training, as a clear area of study, is a recent phenomenon (Airey, 1988). Significantly, Jasper (1987: 580) points out that it developed in an ad hoc and unplanned manner in most countries and curriculum relevance and skills development have been questioned (Airey and Tribe, 2005; Baum, 2002). Other debates are on standards in tourism education, shortages of tourism educators, industrial involvement in curriculum development and accreditation of courses.

In line with the debates, Baum (2002) notes that this debate is dynamic, controversial, and provides rich agenda for researchers. Also, it has both academic and political interest, making the issue quite unclear, hence

*Corresponding author. E-mail sarkache@yahoo.com. Tel: 0722-875590. the industry participation will give an appropriate feedback about employees' competences and attempt to address some of these issues. The Kenyan hospitality industry evolved at the coast due to Arab traders and the railway line construction workers. Their presence necessitated the building of the first catering establishment at the coast which was known as the Grand Hotel of Mombasa built at the present site of Manor Hotel. After the country fell under the British colonization, there was need to access Uganda and the railway was constructed leading to more catering units established along the railway line for the workers. By 1960, some hotels such as Norfolk had reached international five stars rating. Later in 1975, hospitality training was also started at Kenya Utalli College but as Mayaka (2005) reports, had a limited capacity. To supply the growing demand, there was proliferation of private and public universities and colleges which had a varied curriculum. All these institutions had no linkages in terms of hospitality curriculum, no networking and the regulatory and harmonizing body was still in the formative stage (Mwaisaka, 2004; Sio, 2000). Now, the Ministry of Education is in the process of 
harmonizing the hospitality curricula. This has taken a lot of time since it involves several bodies like Kenya Institute of Education, Catering and Tourism Development Levy Trustee among others stakeholders. Each body has its own curriculum slightly different from the other. Colleges using international curricula like City and Guilds have met all the requirements.

Hotels are classified after consideration of several factors affecting the overall standards, for example, standard of cleanliness, manner of storing, preparing and serving food and the quality of food (Laws of Kenya, 1986). The classification is in such a way that the higher the stars, the better the quality of service expectations, standards and overall structure and amenities (Baum, 2002). Hence, the employer requires employees with requisite skills and high competences. In a recent stakeholder's forum (Mwaisaka, 2006), an appeal was made to the government to regulate the hospitality training of personnel which was meant to protect the industry from the falling standards occasioned by the mushrooming of bogus colleges. These colleges are not registered by the Ministry of Education and lack the required facilities and trained lecturers. In line with this, falling standards amongst the hospitality employees were observed by the (United Nations Educational, Scientific and Cultural organization, 2004/2005). There is an ongoing taskforce by Kenya Institute of Education (KIE) which was to harmonize training in Kenya as a result of Sessional Paper No. 1 of 2005 that saw technical Industrial Vocational Entrepreneurships Training (TIVET) not being responsive to the labour market needs. To date this harmonization has not been completed. However, Kenya National Accreditation Service (KENAS) has been established through a legal notice. This will be the sole accreditation body in the country.

In connection with the training harmonization, the tourism education should be a step ahead of the industry with new technology, new innovation and development. The industry should learn from the educators and vice versa. The situation in Kenya is that the academia learns from the industry, although there is no organized method of knowledge transfer. The industry is yet to develop fullyfledged research department which can research and disseminate information.

Previous related studies by Austra and Asta (2009) and Mayaka and King (2002) observed a mismatch of the learnt skills and those needed in the industry. Mayo (2003) suggests that there is need to ensure that students acquire relevant competences to serve as productive employees. This can be achieved by the hospitality training providers impacting the necessary skills for a given competence. This is supported by Agut et al. (2003) who suggested that all sets of competences are required for effective management. The study focused on the hotel managers and no information was gathered from the human resource managers. Also, the lower level employees who are vital in quality service did not give information. Such information on employees' competences is important for industrial growth.

There are several empirical studies done on employees' competences but very little research has been documented in Kenya despite that relevantly trained workforce is critical in enhancing destination competitiveness. In addition, Brophy and Kiely (2002) had recommended that a competence research be conducted in four and five star hotels. This study aimed at determining the Hospitality Industry employers' expectations on employees' competences and skills.

\section{Hospitality industry expectation}

The hospitality industry is complex and dynamic and so its definition remains open to ongoing debate and research (Brotherton, 2004; William, 2004; Jones, 2004 in Hemmington, 2007). Slattery (2002) challenges the three main domain approaches of social, private and commercial environment. This is due to the fact that it excludes important aspects of the industry; instead, he views hospitality industry, co-oporate and venue-context (Lashely and Morrison, 2000), from philosophical and commercial perspectives to include several interesting perspectives such as humour and others. Hemmington (2007) points out the debate on unclear definition of the hospitality industry as a limiting factor in the industrial growth and development. The present study includes both commercial and non-commercial aspect of the hospitality industry. The author wished to find out in the midst of this definition debate whether the employers know the competences they expect from the employees.

When expectation matches perception, Ladkin (2005) suggest that quality results. Critics like Said and Henkerson (2005) suggest that trainee exiting colleges should be ahead of the industry to keep abreast with times, and also help the industry cope with the emerging changes and introduce innovations. The current position is quite different the trainee learns a lot from the industry due to the presence of modern equipment and improved methods of service.

The Kenya National Development Plan (2002 to 2008) states that Kenyan certificates are not accredited (Kenya, 1998). This is due to the fact that there has been no accreditation body to-date, although plans are underway to have one. These certificates do not indicate expected competences from the graduates. The employers may have to either guess on what they are competent in or retrain the new employees even in areas they had already trained in. Such lack of clarity would lead to loss in profitability due to poor quality service.

Various researchers reveal that in different countries employers expect employees' to possess different skills. Burgess and Aitken (2004) in their survey of employers revealed functional, conflict resolution, computer skills and good work habits as the expected. They also 
revealed chronic shortages of chef's skills, kitchen, housekeeping, management, sales, enterprising and customer service. The industry expectation varies as per country being researched. There seems to be skills and competency that are common to all researchers like customer service, technical skills and management that the industry expects an employee to possess in order to be competent. Burgess and Aitken (2004) did not address skills and competence in the form of understanding the level of service expected by international guests, multi-skilled and self-initiative.

The chronic shortage of skills revealed may suggest that the educators do not impart them during training. An implication that would mean that the employees' lack competences since they do not have the requisite skills. This will definitely hurt the industry as there will be no quality service, the government should move faster and address issues affecting hospitality training.

Cotton (2002) identified people management, influence, communication, developing relationships, planning, analyzing information, decision-making, commercial awareness and resilience as competences which every employee should possess. In addition, Glmore and Gregor (2001) established characteristics such as honesty, code of ethics, appropriate appearance, fairness, respect and good working relationships as important. Punctuality, cautiousness, reliability and trustworthiness were considered as professional behaviours. Like Burgess and Aitken (2004), Cotton (2002) and Gilmore and Gregor (2001) also omitted the same skills and competency. This implies that the industry should give quality service that the employees need to have competency in the certain skills sets. These skills are the special ability gained by learning and practice. Managerial competences fall into two categories: the technical and generic. Technical managerial competence consists of having knowledge and skills that enable the manager to give an effective performance in specific areas of management. Generic managerial competence refers mainly to manager's capability of self-regulation and self-control in job development.

There are several debates on skills and competences required in today's workplace. Brophy and Kiely (2002) suggested the need for an innovative and fresh approach to human resource management within the Irish hotel sector. Various authors have suggested that a competent employee must contribute to customer satisfaction amongst other things (Wikipedia assessed 27/9/11; Nwenre, 2005). Hence, a competent employee should have a cluster of skills and attitude that affect a major part of one's job (Nwenre, 2005). This is the only way we can get quality service in the hospitality industry (Agut et al., 2003) identified a negative gap in most technical managerial competencies (knowledge and skills) the highest knowledge need was in economic financial management and the highest in skill was computing.

Kenya Hospitality Industry needs were noted by Woolf
(1990), to include satisfying all clientele, possess management, communication and motivational skills, knowledge of the company objectives, expectation and behaviour of different classes of guests, management of people, use of control information, problem analysis and decision-making. Other skills are functional skills such as housekeeping, catering and customer care. Finally, he reveals that employees do not have inherent understanding of the level of service expected by international guests, also the knowledge of culture and value system of different nationalities. The varied findings call for a need for standardization and hence Fabricus (2002) advocates that Tourism education quality (TEDQUAL) should produce guidelines to industry standards.

Hospitality Industry criticized tourism education for not adequately preparing people for employment in the industry (Airey, 1988). An understanding of how best to educate and develop human capital would benefit tourism industry as a whole (Landkin, 2005). The hospitality industry should develop its standards and expectations. Mayaka and King (2002) employer's opinion of the tour guide employees' skills is a useful assessment of training and education quality. Such a survey in hospitality industry may reveal the gap in education and training and hence be used to identify the competencies required in the industry for quality service.

Currently, employees' competences depend on skills acquired during training. The quality of service depends on the competency in these skills. Sola et al. (2002) advocate an effort to foster skills which correspond to the contemporary industrial needs. The School of Tourism of Eastern Mediterranean, a TEDQUAL certified centre emphasizes a demonstration kitchen, training hotel and computer programme. Many training providers in Kenya lack the aforementioned and so graduates' competences in the contemporary industry raises eye brows. Despite the fact that every hotel has a kitchen, the Kenya hospitality industry and the academia are not well-linked so that each can benefit from each other. Some of the trainees are trained on theory only and get the practice during industrial attachment. Such students will not acquire the necessary skills to be competent enough to give high quality service.

Eastaff (2002) suggests that skilled employees should have personal attributes. This includes people with passion and the right attitude, foresight, creativity, confidence, ability to motivate flexibility and respect for others. Business skills were suggested as follows; business focus, sales orientation, financial acumen, entrepreneurial skills, good customer relationship, good relationship with the hotel owners, a diplomat and a negotiator. Other skills necessary to facilitate success are that the hotel should be a learning organization not a training centre.

Other previous researches by Burgess and Aitken (2004), Mayaka and King (2002) support that industry should play a central role. However, Sola et al. (2003) 
worldwide research on employers' satisfaction generally lacks specific details for each country making the present study timely (Wandongo et al., 2010), their study identified the need for the hotels and training institution to enhance acquisition of generic managerial competences. The skills therefore under study are a collection of what other researchers had previously identified for an employee to possess in order to be considered important and establish any relation in the results.

\section{Conceptual framework}

The study was based on the Haywood and Maki (1991) model in which they argue that quality exists when expectation matches perception. In identifying quality, employer and employee are identified as some of the primary stakeholders. Thus, the research focused on the skills and competencies employee had as they left the training providers against the industry employers' expectation as per the hotel classification. The current environmental factors influencing the interface are beyond the scope of the present study. Moreover, it is clear that the needs, practices and training output of educational institutions help in achieving practical human resource management. Training and selection of employee is the key in fighting to enhance destination competitiveness. Therefore, the present study considered employers and employees but not educators and education recipients who may be incorporated in a followup study (Figure 1).

\section{RESEARCH METHODS}

A stratified sample procedure was used for the preliminary sampling of the hotels. The data from this study were collected at 8 out of the 27 classified town hotels and restaurant (Gazette, 2004).

This is $29.6 \%$ of the 1 to 5 star rated town hotels and restaurants from Nairobi. The location was chosen as it has a good number of classified hotels. The classification of the hotels is based on quality of product and services offered. Quality service is usually given by competent employees who have the requisite skills and competences. The unit of observation was purposely selected from department heads such as executive chef, executive housekeeper, front office manager and food and beverage manager because they have the required information. To validate the responses, two employees were randomly selected from each department making a sample of 106 (56 managers + 56 employees). To correct ambiguity in the instruments pre-test was carried out in a one star hotel. A human resource manager, 4 departmental heads and 8 employees took part in the pilot study. Consulting experts in the industry also collected for more information (Table 1).

\section{Data collection procedure}

An interview guide was prepared for the HRM and two different versions of questionnaire were created for the HOD and the employees. A face-to-face interview guide was done on the HRM and were to rate the importance of how the industry expects on

\section{NEEDS AND PRACTICES OF EDUCATION} INSTITUTIONS

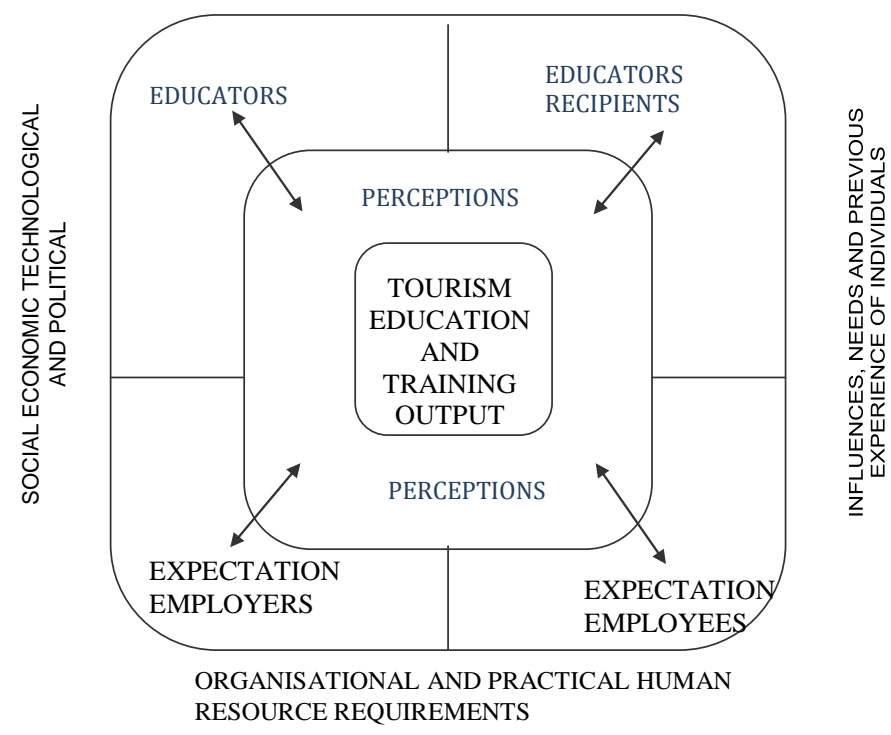

Figure 1. Interface between training education and employment. Adapted from Haywood and Maki (1991: 106).

employee to be competent on some given skills. They were to indicate on whether the skills are; not important or important. This design took into account information from studies in the industry and the result from previous studies (Wadongo et al., 2010; Mayaka and King, 2002; Agut et al., 2003). The HRM was to select from a list of skills similar to those given to the HODs and were to select the skills they think the industry expects the employees to be competent in. They were to select from communication skills, specific technical skills for the trade, conflict resolution, computer skills, good work habits, information technology, customer service, sales and marketing, good interpersonal skills, multi-skilled, selfinitiative, self-discipline, self-motivation and understanding the level of service expected by the international guests. The employees were given questionnaires in which they were to indicate the competency employers expect them to have on employment. This was used as recommended by Agut et al. (2003). They were to select from the following; basic skills, technical skills, interpersonal skills, computer, self-initiative, trainable person and good attitude towards work. The researcher contacted the hotel managers to obtain approval. The purpose of the study was explained to the human resource manager or the head of department. The researcher personally administered the questionnaires and conducted interviews.

\section{Data analyses}

The responses were assigned numerical values categorized as interpreted and connected to consistent numerical codes. The dependent variables were, industry expectation, employee competence, quality gaps and skills gap. The independent variables were years of training and employee expectation. The coded data were tabulated and edited for computer analysis using scientific package for social sciences (SPSS). Data were presented in tables of frequency distributions, graphs and percentages. Chi-square $\left(x^{2}\right)$ was used to measure whether there is a significant relationship between skills expected by the hos-pitality industry employers and the hotel classification. The hotels were divided into two groups; those below and above three stars. This level of three stars was 
Table 1. Sample size.

\begin{tabular}{cccccc}
\hline $\begin{array}{c}\text { Respondent } \\
\text { Town hotel }\end{array}$ & $\begin{array}{c}\text { Number of } \\
\text { hotels present }\end{array}$ & $\begin{array}{c}\text { Number of } \\
\text { hotels selected }\end{array}$ & $\begin{array}{c}\text { Number of } \\
\text { managers }\end{array}$ & $\begin{array}{c}\text { Number of } \\
\text { managers selected }\end{array}$ & $\begin{array}{c}\text { Number of } \\
\text { employee }\end{array}$ \\
\hline 5 & 7 & 2 & 56 & 10 & 16 \\
4 & 1 & 1 & 8 & 5 & 8 \\
3 & 11 & 3 & 88 & 15 & 16 \\
2 & 4 & 1 & 32 & 10 & 8 \\
1 & 4 & 1 & 32 & 10 & 8 \\
Total & 27 & 8 & 216 & 50 & 56 \\
\hline
\end{tabular}

used because it is a transitional point. Below it are the hotels where the quality of service expected is not very high. The assumption being that the employees were not expected to be competent in many skills. Above it are high class hotels where high quality service is expected from high competent employees. To be competent, one is expected to possess a wide range of skills and knowledge. The skills selected are those that are essential in the industry and which contribute to competency and quality service.

\section{RESULTS AND DISCUSSION}

Data were collected using questionnaires and face-toface interview schedules. The data collected were analysed using frequencies, bar charts and percentages. The results were presented under the following sub-topics; hospitality industry employers' expectations on employees' competences and the difference between hospitality industry's expected skills in different hotel classification. To establish the attainment of the objectives, percentages were used and the formulated hypotheses were tested using chi-square $\left(\mathrm{x}^{2}\right)$ and multinomial logistic regression. All hypotheses were either accepted or rejected at $p<0.05$ acceptance level.

The respondents (HOD and HRM and employees) were asked to identify skills the industry expects the employee to be competent in. HOD and HRM were considered as the employers while the middle level employees were considered as employees (Figure 2).

At the management level, also taken as the employers, the skills with the highest expected competences were: Conflict resolution (54\%) followed by self-initiative (38\%), sales and marketing (35\%) and understanding the level of service expected by international guests (31\%). Since today's manager is expected to have this amongst the key skills. The result reflects a disparity on skill expectation level as ordinarily expected.

The results also revealed that expected skills for one to be considered competent were self-motivation (29\%), specific technical skills (23\%), good interpersonal skills $(22 \%)$ and information technology (22.5\%). This again reflects a low percentage than expected (100\%) Also, there is a need for the training providers to have the knowledge of the expected skills and inculcate them appropriately. Other expected skills were communication (17.1\%), computer skills (18.4\%) and good work habits
(15.4\%). Also, customer service (17.1\%) followed by multi-skills (19.4\%) and self-discipline which had (14.6\%). This finding is interesting in the light that managers do not value human relation competencies (Wandongo, 2010).

The respondents indicated that the employees were expected to have good work habits (44\%), computer $(42.12 \%)$, self-discipline (43.9\%), communication (41.5\%) and information technology (46.2\%). From the data, mentioned skills were more preferred even though the percentages were still not high enough as expected. The expected skills by the respondents were self-motivation, (39\%) customer service, (39\%) multi-skills (39\%), understanding service level of international guests (38.5\%) and sales and marketing (38\%). This may imply that these skills are the next in importance.

A small percentage $(29.7 \%)$ expectation was for conflict resolution and self-initiative (30\%). The results contradict the current employer expectation that goes for selfinitiative employee who can resolve conflict at the place of work. Such findings give an impression of an industry lagging behind the current moves regarding modern management since this is what is being emphasized in today's high performing organisations. The low percentage response may indicate that even the employers are not aware of the importance of some skills. It is very possible that seeking industry advice on what skills are necessary will not reveal a positive outcome. This of course, results in a very exciting outcome of the study. This small expectation is unexpected as there is a global shift to information technology, computer knowledge, selfdriven personnel and international hospitality. Furthermore, these skills have previously been identified as key to the success of the industry by Austra and Asta (2009). The hotel industry seems to lag behind on this perhaps because the educational institutions are not fully linked and not ahead of the industry.

The academia may not probably be interested because they are not fully aware of what the industry requires. This is the challenge in almost all countries where educators do not only know what is needed in the industry. This contradicts Sadi and Henkersons' (2005) suggestion that educators should know industry needs but also be innovative with new skills and ideas that can enhance service delivery. 


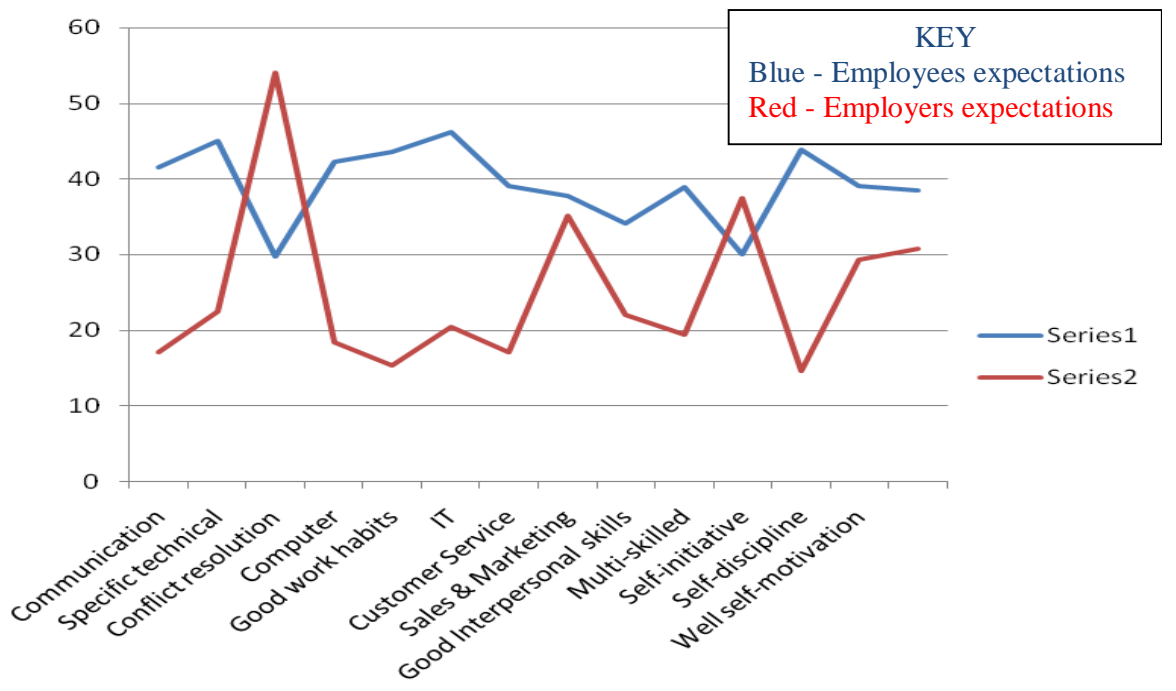

Figure 2. Management (employers') and employees' expectations on employee competences.

The results also imply that the industry is quite specific on the skills expected from the employees. Maybe this means that industry wants to have their own on-job training, instead of formal training in hands off institutions. The challenge would be that the industry would be overwhelmed with the training at the expense of their core business of giving quality service to their customers. The results confirm the gap between industry and training institutions as cited by UNESCO (2004/2005).

An analysis of employees' expectations by different hotel classifications was carried out. The few skills expected are quite essential in the industry and a difference in expectation would draw a significant attention (Table 2).

Table 2 shows that there is a significant difference on employee's expectations by the middle and management level among the rated hotels in communication $(p=0.99)$, conflict resolution $(p=0.07)$, customer service $(p=0.46)$, multi-skills $(p=0.81)$, self-motivated $(p=0.81)$ and understanding the level of service expected by international guests $(p=0.92)$. It is only in computer skills $(p=0.04)$ where there was no significant difference. This might be attributed to the global computerization. The significant differences in skill expectation concurs with Baum's, (2002) observation that high class hotels emphasize on skills competence; it also contradicts an earlier finding that high rated hotels prefer public trained employees because of quality service. This may be because there are no industry standards to refer in terms of skill expectation. The significant difference in computer skill expectation is an indication that the higher rated hotels are more computerised. The possible explanation is that Kenyan ICT policy is being put in place though this will depend on how it is implemented.

The employees were asked to indicate the skills employers expect of them on employment. They were to select from basic skills, technical good attitude, trainable, interpersonal skills, computer self-initiative and others (Figure 3).

Out of the total employees, $(90.9 \%)$ indicated employers expected them to have basic skills, $(85.5 \%)$ good attitude and (82\%) trainable person. Other skills that were second in importance included interpersonal skills (82\%), self-initiative $(74 \%)$. Notably, these percentages are as expected in all industries. Skills that were relatively least expected were technical skills (63\%), computer skills $(63 \%)$. Others (29\%) included good grooming, product knowledge, public relations, self-esteem, management skills, handling computers, customer care, general knowledge and self-discipline. Since the current curriculum does not include some of these, there is a general perception that gaps exist. The varied percentages are not in line with Sadi and Henkersons' (2005) idea that employee exiting colleges should be ahead of the industry as there exists a skill gap. Some of the small percentage responses on key skills indicate a gap on employers' standards. For instance, some of the important skills are good grooming, customer care and product knowledge which are highly considered as important to the employee.

\section{CONCLUSION AND RECOMMENDATION}

The study found that there is a relationship between the skills expected by the hospitality industry employers' and the hotels' classification. It is only in computer where there was no significance relationship $(p=0.04)$. Practically, some of the skills with significant relationship like customer care, multi-skills, communication and 
Table 2. The difference between hospitality industry expected skills in different hotel classifications.

\begin{tabular}{|c|c|c|c|c|}
\hline Skills/competence & $\begin{array}{c}\text { Employees } \\
\text { n (\%) }\end{array}$ & $\begin{array}{c}\text { Employers } \\
\text { n (\%) }\end{array}$ & $\begin{array}{l}\text { Both } \\
\text { n (\%) }\end{array}$ & P-value \\
\hline \multicolumn{5}{|l|}{ a) Communication } \\
\hline$\leq 3$ Star & $7(17.1)$ & $3(7.3)$ & $7(17.1)$ & 0.99 \\
\hline > 3 Star & $10(24.4)$ & $4(9.8)$ & $10(24.4)$ & \\
\hline \multicolumn{5}{|c|}{ b) Conflict resolution } \\
\hline$\leq 3$ Star & $5(13.5)$ & $6(16.2)$ & $5(13.5)$ & 0.07 \\
\hline$>3$ Star & $6(16.2)$ & $14(37.8$ & $1(2.7)$ & \\
\hline \multicolumn{5}{|l|}{ c) Computer } \\
\hline$\leq 3$ Star & $5(13.5)$ & $6(15.8)$ & $6(15.8)$ & 0.04 \\
\hline$>3$ Star & $11(28.9)$ & $1(2.6)$ & $9(23.7)$ & \\
\hline \multicolumn{5}{|l|}{ d) Customer service } \\
\hline$\leq 3$ Star & $8(19.5)$ & $4(9.8)$ & $6(14.6)$ & 0.46 \\
\hline$>3$ Star & $8(19.5)$ & $3(7.3)$ & $12(29.3)$ & \\
\hline \multicolumn{5}{|l|}{ e) Multi-Skilled } \\
\hline$\leq 3$ Star & $8(22.2)$ & $4(11.1)$ & $6(16.7)$ & 0.60 \\
\hline S> 3 Star & $6(16.7)$ & $3(8.3)$ & $9(25.0)$ & \\
\hline \multicolumn{5}{|l|}{ f) Self-Motivated } \\
\hline$\leq 3$ Star & 8 (19.5) & $5(12.2)$ & $5(12.2)$ & 0.81 \\
\hline$>3$ Star & $8(19.5)$ & $7(17.1)$ & $8(19.5)$ & \\
\hline \multicolumn{5}{|c|}{$\begin{array}{l}\text { g) Understanding the level of service expected by } \\
\text { international guests }\end{array}$} \\
\hline$\leq 3$ Star & $7(17.9)$ & $6(15.4)$ & $4(12.8)$ & 0.92 \\
\hline$>3$ Star & $8(20.5)$ & $6(15.4)$ & $7(17.9)$ & \\
\hline
\end{tabular}

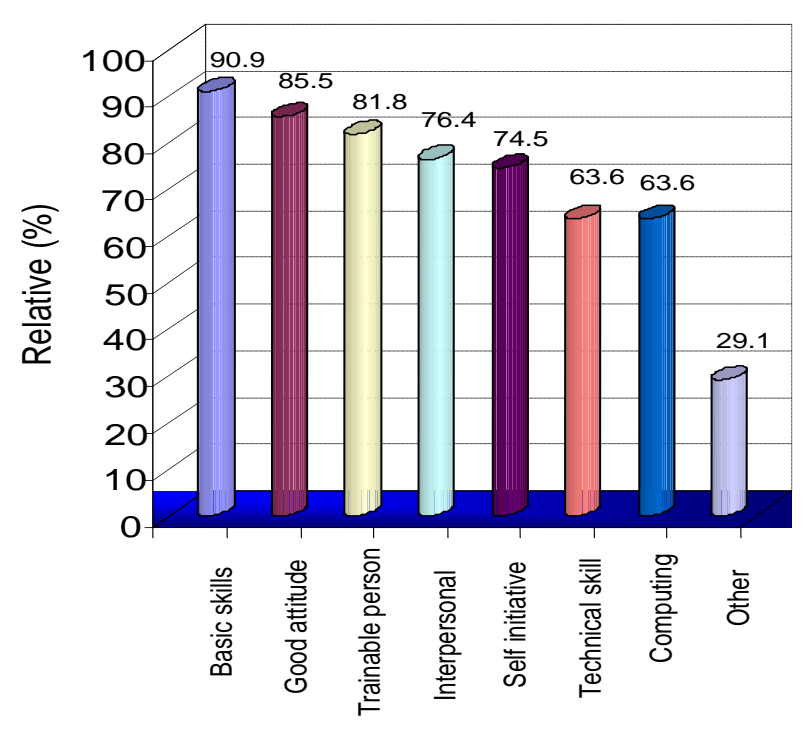

Industrial skills expectations

Figure 3. Industrial skills expectations (in relative \%) by employers in the hospitality industry. understanding the level of service expected by international guests are expected in any hotel irrespective of its classification. Such a relationship may imply low quality service since the difference in hotel classification should be mainly on facilities available.

There is a notable difference between managers and employees' expectation. The biggest difference in the expectations seen is that many employees think that the industry expects them to be competent in communication skills, specific technical skills, computer, good work habits, customer service and self-discipline. In contrast, the employers least expects them to have these skills. It is only in conflict resolution and multi-skilled where the managers' expectation is greater than that of the employee. This also indicates that the employers and employees are not fully aware of the industry expectations.

The contemporary management considers the skills and competence considered as next in importance as crucial for the success of any business. The specific technical skills and good interpersonal skills are important in the provision of quality service in the hospitality industry. In fact the employees thought that the employers 
expected them to have them but the employers did not consider the skills important. The results indicate an obvious disconnection between the employee and employers and also between the industry and training providers.

The skills that were referred to others (29\%), are considered as important in the industry. This may also indicate that the skills are not given adequate attention during on-job training and in the learning institutions.

The hospitality industry expectation of skills is varied at different levels of employees. The value of expectation is considerably lower than expected. This is because the high expectation ranges from 42 to $46 \%$ of those interviewed. These results are not in line with modern or current management where their expectation is high despite the fact that there is no benchmark for the expectation. This is seen in some critical skills like communication skills, computer, self-initiative and multi-skills which are among the least expected skills. The hospitality industry and its curriculum seem not to be evolving in response to the industry and technological changes. The employees should be encouraged to have competitive skills in problem-solving, creativity and originality. It is also recommended that a professional body to address the issues in the hospitality industry be established. This body should participate in the hotel classification research and also develop hotel standards which all employers, employees and other stakeholders understand. The body should create a forum where managers/ employers should be exposed to the contemporary managerial competences. A closer link or collaboration should be established between the training providers and the hospitality industry so that the employees exit colleges knowing industry expectation and vice versa. This will go a long way in improving the quality of service.

\section{LIMITATIONS AND FUTURE RESEARCH}

This study has some limitations. First the HODs and HRMs were referred as employers while in most cases they were also employees meaning that the actual employer expectation was not obtained. The selfassessment of the employees may not give the correct information as they may not know exactly the skills and competences expected from them. Other respondents such as educators, educator recipients were not included in the research because the study limited itself to hospitality industry personnel. The size of the sample also limit generalisation of results to other managers from the hospitality industry. Future research should address this limitation in other segments of the hospitality industry and geographical locations. A similar study should be replicated to other sectors not covered by this study. Further future research should find out why the hospitality industry is not aware of the skills its employee are expected to poses in order to be considered competent.

\section{REFERENCES}

Airey, D. (1988). Cross cultural approach to teaching tourism: Teaching Tourism in to the 1990's. First International Conference for Tourism Educators, University of Surrey, U.K.

Airey D, Tribe J (2005). An International Handbook of Tourism Education, Elsevier London.

Agut S, Grau R, Peiro JM (2003). Competency needs among managers from Spanish hotels and restaurants and their training demands. Int. J. Hospitality Manag., 22(3), 281-295

Austra R, Asta S (2009). Small medium sized hotel employee core competencies and their development. Int. J. Strateg. Manag., 9(2): 2$6 . \quad$ Retrieved from http://www freepatentsonline.com/article/International-JournalStrategicManagement/20..

Baum T (2002). Skills and Training for the Hospitality Sector: a review of issues. J. Vacat. Educ. Training, 54( 3). http://www.triangle.co.uk. Accessed on 5/11/2005.

Brophy M, Kiely T (2002). Competences a new sector. J. Eur. Ind. Training, 26(2/3/4):165-17

Brotherton,B. (2004). The International Hospitality Industry Structure: Characteristic and issues. Butter worth, Heinemann.

Burgess C, Aitken L (2004). Report On Core Research On Unitising Curricula. http://www.isda/curriculam/core/interim report. Unitising pdf, accessed on 15/12/2004.

Cotton B (2002). Industry and Education in partnership in Graduate employability. Conferencereportlondonfile;//C:IWINDOWSIDesktoplGraduate\%20E mployability\%20 inHospitality\%20confere....accessed on 5/2/2006

Eastaff T (2002). Industry and Education in partnership in Graduate employability.

conferencereportLondonFile;//C:IWINDOWSIDesktoplGraduate\%20E mpl oyability $\% 20$ inHospitality $\% 20$ confere... accessed on 5/2/2006

Fabricus M (2002). South Africa. In: Sola EF, Alcade E, Demis R, Jacobson L, Arenosa JM, Munios A (Eds.). TEDQUAL (1) Madrid: World Tourism Organisation.

Gilmore, Gregol MB (2001). Developing Professionalism in a Hospitality Undergraduate Programme. J. Hospitality Tourism Educ., 13(3): $14-$ 19.

Gazette. (2004). The Kenya Hotel Classification; Volume CVI Number 6 . Authority of Republic of Kenya.

Haywood M, Maki K (1991). A conceptual model for education and employment interface for the tourism industry. Proceedings of the New Horizon in Tourism and Hospitality Training and Research Conference, Calgary, Canada, July. World Tourism and Research Centre, Calgary University. pp. 105-18.

Hemmington, N. (2007). From service to experience. Service Ind. J., 27(6). Retrieved from http:/wwweprintsbournemonth.ac.uk/836/hemmington-output 4ppd.

Jasper, G. (1987). International Harmonization of Tourism Education. Ann. Tourism Res., 14(4) 580-582.

Laws of Kenya (1986). The Hotel and Restaurant Act, Chapter 494. Government of Kenya Printer. Nairobi, Kenya.

Republic of Kenya (1998). National development Plan (2002 - 2008), Effective Management or sustainable Growth and Poverty Reduction.

King B, Smith, SC (2005). East Africa. In: Airey D and Tribe J (eds.), An international Handbook of tourism education, University of Surrey U.K. Elsevier, Amsterdam.

Ladkin, A. (2005). Careers and Employment. In: Airey D and Tribe J (eds.), An international Handbook of tourism education, University of Surrey U.K. Elsevier, Amsterdam.

Mayaka M, King B (2002). A Quality Assessment of Education For Kenya Tour Operations Sector. Curr. Iss. Tourism, 5(2): 112 - 133.

Mayaka M (2005). East Africa. In: Airey D and Tribe J (eds.), An international Handbook of tourism education, University of Surrey U.K. Elsevier, Amsterdam.

Mayo, R.C.(2003). Essential Competence and Critical Performance Measures by Hospitality and Tourism management graduates. Delaware University, http//: www. hie business. org. accessed on 25/1105.

Mwaisaka, PD (2004). Hotels Given New Star Rating. Saturday Nation $27^{\text {th }}$ November, Nairobi. p 13. 
Mwasaka PD (2006). Stake holders meeting. Sunday Standard Nation $16^{\text {th }}$ April, Nairobi. p 5.

Nwenre M (2005). Hotel online Special Report. Core competences Retrieved from http://www.hotel-online.com/news/pr 2005-3rd

Republic of Kenya (1998). Masterplan on Education andTraining19912010, Vocational and Technical Education and Training. Nairobi Goverment Printer. $\mathrm{p} 11$.

Sadi NA, Henkerson JC (2005). Local Versus Foreign Workers in the Hospitality and industry: a Saudi Arabia perceptive. Cornel Hotel Restaurant Adm. Q., 46(2): 247-257.

Sio M (2000). International Human Resource Management in the hospitality industry. In: SM Johnson C, Lefever M (eds.) Educational institute, American Hotel and Motel Association, USA.

Slattery P (2002). Finding the hospitality industry. J. Hosptality Leisure Sport Tourism Educ., 1(1):1-26 Retrieved from http://www.hlst.itsn.ac.uk/johlste.

Sola E, Navaratha F, Kathirevelu (2002). In: J Siera, R Dle (Eds). Perception of employer regarding outcome of training programmes and the factors inhibiting achievement of those outcomes. Australia: Academic Press.
UNESCO (2005). Kenya and UNESCO Annual Report, 2004/2005. Kenya National Commission for UNESCO.

Wadongo B, Kambona O, Odhuno E (2010). Emerging critical managerial competences; A challenge to educators in Kenya. Afr. J. Econ. Manag. Stud., 2(1): 1-2.

Wikipedia Retrieved from http://en. Wikipedia.org/wiki/core-competence William A (2004). Understanding the Hospitality Consumer. Elsevier Butterworth, Heinemann Oxford.

Woolf $P$ (1990). Human side of Hotel Management in the Hotel Industry in Kenya. Pricewaterhouse, Nairobi, Kenya. 